\title{
Using Social Marketing Principles to Describe Local Isfahan Managers' Attitude about Using New Energy Resources
}

\author{
Hussein Rezaie Dollatabady \\ Department of Management, Faculty of Administrative Sciences and Economics \\ University of Isfahan, Isfahan, Iran \\ E-mail: ho.rezaie@gmail.com
}

Farham Amiri (Corresponding author)

Faculty of Administrative Sciences and Economics

University of Isfahan, Isfahan, Iran

E-mail: Farham.amiri@yahoo.com

Olfat Ganji Bidmeshk

Faculty of Administrative Sciences and Economics

University of Isfahan, Isfahan, Iran

E-mail: olfat_022@yahoo.com

$\begin{array}{ll}\text { Received: October 3, } 2011 & \text { Accepted: April 12, } 2012 \quad \text { Published: June 1, } 2012 \\ \text { doi:10.5539/ijms.v4n3p160 } & \text { URL: http://dx.doi.org/10.5539/ijms.v4n3p160 }\end{array}$

\begin{abstract}
Objective: Though rich in oil and gas, Iran, like many other countries in Middle East, increasingly recognizes the need to diversify energy sources, to ensure security of supplies and provide for more consistent energy costs. Renewable energies (e.g. wind, solar and geothermal) are realistic options without the environmental impacts of conventional fuels. Developing and using of this renewable resources and changing energy policy, was under the influence of managers' Attitudes and consequently their support of this strategy. The purpose of this paper at first is to understand managers' values about the new energy resources, and then to analyze the impact of social marketing mix on Managers' feelings.

Methods: The paper employed structural equation modeling (SEM) to investigate the relationship between the social marketing and Attitude. Required data were collected from local managers in Isfahan by questionnaire method. For Data gathering and analyzing mixed (qualitative and quantitative) Methods are used.

Results: findings show that managers' Attitudes towards new energy resources were positive. Also, the current social marketing mix (e.g. product, price, place, promotion, people and policy) of new energy centers are suitable. As another result, managers' Attitudes cannot influence on the social marketing mix.

Conclusion: The paper recommends the integration of principles of social marketing in community programs aimed at dealing with environmental issue. In particular, it suggests identification of competing groups in the community, construction of specific programs for different segments, addressing the no-monetary prices that the change may incur on the different groups, location of appropriate places for distribution of messages, using supportive laws, indentifying people views and using TV media and Internet services as well as public means of communication and promotion.
\end{abstract}

Keywords: Social marketing, Attitude, New energies, Marketing mix, SEM

\section{Introduction}

Burning fossil fuels (e.g. oil, gas, coal), on the one hand, produces greenhouse gases such as $\mathrm{CO}_{2}$ and $\mathrm{CH}_{4}$ which have an impact on the global climate, and, on the other hand, also environmental pollutants that severely impair people's health. Environmental aspects and quality of life indicate that environmental pollution (of air, water, 
etc.) is largely linked to the increasing use of energy, presently the climate changes due to heavy use of fossil fuel (Akella et al, 2009). In Iran also, CO2 is the most important greenhouse gas, approximately 364 million tons of CO2 emissions were produced in 1994. The per capita quantity of emissions amounted to 5.69 tons (Massarrat, 2004). Other pollutants such as sulfur dioxide (SO2), nitrogen oxides (NOx), hydrocarbons, heavy metals, and dust which also emerge trough the burning of fossil energy sources are the cause of significant damage to people's health, above all in conurbations, and consequently of high external costs for the national economy (Massarrat, 2004). In order to avert climatic catastrophes with unforeseeable consequences for mankind, the world's greenhouse gas emissions would need to be drastically lowered and reduced to zero towards the end of the $21^{\text {st }}$ century. In the long term, this would imply completely replacing fossil energies by other energy forms, especially renewable energy sources. Though rich in oil and gas, Iran, like many other countries in Middle East, increasingly recognizes the need to diversify energy sources, to ensure security of supplies and provide for more consistent energy costs. Renewable energy (e.g. wind, solar and geothermal) is realistic options without the environmental impacts of conventional fuels. Development and use of this renewable resources and shift in energy policy, was under the influence of managers' Attitudes and consequently their support of this strategy. To fully understand Attitudes and how they change, knowing the factors that influence Attitudes is necessary. Attitudes are not isolated, but reflect the Beliefs and values which a person holds (Schafer, 1986). At the first, it is necessary to understand the Attitudes of managers, and then change these Attitudes by increasing the knowledge and Beliefs if their Attitudes were undesirable.

One identified and efficient approach to influencing on and changing Attitude is using social marketing principles.

Marketing scholars first addressed environmental issues in the 1970s with the emergence of the concepts Ecological Marketing. These Concepts largely represent an environmentally-orientated extension of Societal marketing (Peattie \& Peattie, 2009). Contemporary Social marketing was born as a discipline in, when Philip Kotler and Gerald Zaltman realized that the same marketing principles that were being used to sell products to consumers could be used to sell ideas, Attitudes and behaviors (Mohesh, 2007). This term Drawing from bodies of knowledge such as psychology, sociology, anthropology, political science, and communication theory-with practical roots in advertising, public relations, and market research (Serrat, 2010), to alter an individual's perceptions and Attitudes (Wymer, 2010). In this study, at first authors tried to use social marketing principles for describing current managers' Attitudes, then they investigated current social marketing mix and finally planned suitable social marketing.

\section{Literature Review}

\subsection{Attitude}

In our everyday lives, Attitudes play a major role in affecting our behavior. They influence how we feel and behave toward others in our environment. Attitude has an important influence on our decisions. An Attitude is viewed as an association in memory between a given object and one's evaluation of that object (Overwalle \& Siebler, 2005). Attitudes meaning that are feelings, Beliefs and tendencies to act toward other persons, groups, ideas, or objects (Schafer, 1986).

\subsection{Beliefs}

The information a person has about an object will influence the Attitudes that person holds about that object. Schafer (1986) defined Beliefs as the knowledge and information which a person assumes to be true about the environment. Many Beliefs may underline a given Attitude. It is necessary to determine as many of these Beliefs as possible before attempting to influence Attitudes.

Individual also use Attitudes to express their basic values and to portray to others the sort of persons they are. Generally, people maintain a consistent relationship between their Beliefs, values, and Attitudes (Schafer, 1986).

\subsection{Values}

Schafer (1986) defined values as the general feelings about what is desirable or undesirable. Individual usually use Attitudes to express their basic values and to portray to others the sort of persons they are. Generally, people maintain a consistent relationship between their Beliefs, values, and Attitudes (Schafer, 1986). The information a person has about an object will influence the Attitudes that person holds about that object. Schafer (1986) also defined Beliefs as the knowledge and information which a person assumes to be true about the environment. Many Beliefs may underline a given Attitude. It is necessary to determine as many of these Beliefs as possible before attempting to influence Attitudes.

Therefore, we considered Beliefs and Values of local managers as antecedents of managers' Attitudes and 
behaviors.

H1: The Beliefs of managers' about new energy effects on Attitudes when is higher than medium.

H2: The Values of managers' about new energy effects on Attitudes when is higher than medium.

\subsection{Social Marketing}

Tellingly, in the 2010s, the attention of public sector agencies, nongovernment organizations, and the private sector is increasingly drawn to the potential of social marketing. In an age of climate change, environmental destruction, natural resource shortages, fast population growth, hunger and poverty, as well as insufficient social services, what contributions might market make? To help address the problems presented by regulatory messages and traditional environmental communications, environmental campaigns have employed a new approach in the past decade: social marketing. Social marketing is exactly what it sounds like, using marketing techniques for social causes (Klein, 2001). The origin of social marketing stems from the discipline of commercial marketing, with Wiebe in 1952 posing the question "Why can't brotherhood be sold like soap?" (Perese et al, 2005). Since its inception in 1971, the term of social marketing has been redefined and subject to debate and discussion amongst academics and practitioners (Andreasen, 2002). However, the common component to all definitions of social marketing is the application of the marketing mix (product, price, promotion and placement) to achieve socially desirable goals. Moreover, most definitions discuss an element of design and control of programmes (Perese et al, 2005). Recently, Dann defined Social marketing as " the adaptation and adoption of commercial marketing activities, institutions and processes as a means to induce behavioral change in a targeted audience on a temporary or permanent basis to achieve a social goal" (Dann, 2010). A key difference between social marketing and traditional environmental communications is that social marketing try to change behavior by changing Attitudes, and this change is permanent and voluntarily. While using persuasion or educational approaches may get a person to agree to a concept, but the social pressures of doing such a behavior may limit them from doing it (Klein, 2001).

Some consider social marketing to do little but use the principles and practices of generic marketing to achieve noncommercial goals. This is an oversimplification: social marketing involves changing seemingly intractable behaviors in composite environmental, economic, social, political, and technological circumstances with (more often than not) quite limited resources. If the basic objective of corporate marketers is to satisfy shareholders, the bottom line for social marketers is to meet society's desire to improve quality of life. (Serrat, 2010)

\subsection{Social Marketing Mix}

The social marketing mix, including product, price, place, promotion, people, partnership and policy is defined as bellow:

Product: in commercial marketing, product considerations include the actual product or service. In social marketing, the product is the behavior that the campaign planners would like the targeted individuals to adopt. (Perese et al, 2005). Although social marketing campaigns can focus on the promotion of a particular type of product, at its heart social marketing promotes a particular proposition (Peattie and Peattie, 2009). Therefore we use proposition instead of product in this study.

Price: In commercial marketing, price refers to the dollars outlaid for the product or service (Perese et al, 2005). In most social marketing interventions, the costs of changing behavior are not financial. Costs may be in terms of time and effort, flectional, overcoming psychological barriers, or even a physical addiction. It is a much more holistic concept than that of economic price, and has much more in common with transaction cost theory derived from economics (Peattie and Peattie, 2009). An understanding of the price can be used to promote benefits for the consumers (Perese et al, 2005). Therefore we use cost of involvement instead of price in this study.

Place: In commercial marketing, place refers to the distribution channels used to make the product available to target audiences (Perese et al, 2005). Since social marketing is not based around physical products, it is not particularly appropriate to talk about distribution or place issues. Social marketing is more akin to services marketing in that the key issue is accessibility (Peattie and Peattie, 2009). Therefore we use Accessibility instead of place in this study.

Promotion: Promotion encompasses all the marketers' efforts to ensure that the target audience is aware of the product and its benefit, its price and where it is available. The promotional mix includes publicity, public relations, advertising, sales promotions and Sponsorship. These promotional efforts are designed to cultivate positive Attitudes and intentions regarding the product that pave the way for behavior change (Perese et al, 2005). Therefore we use social communication instead of promotion in this study. 
People: Many social marketing products are services delivered. And the consumer's experience is dependent on the interaction between the customer and the salesperson (Perese et al, 2005).

Partnerships: By developing an alliance with certain groups, can more effectively reach certain populations (Smith and Strand, 2008, p.61).

Policy: behavior change can effective if occurred at the specific time and place. If not, it is economical that chosen a policy to forced this change (Mohammadi et al, 2005).

In order to understand the suitable social marketing mix from the viewpoint of audience another hypothesis was:

H3: The current social marketing programs of energy centers was higher than medium.

H4: Social marketing mix will have positive relationship with managers' Attitudes about using new energy resources.

Q1: What is suitable social marketing mix from managers' viewpoints?

\subsection{Theoretical Framework}

Insert Figure 1 here

\section{Methodology}

3.1 Sample

All Isfahan local Managers were our sample population for collection data. We distributed 120 questionnaires out of which 108 usable were received back.

\subsection{Measures}

Attitudes of managers were treated as dependent variable. While, social marketing mix such as: promotion, price, product, place, people and policy, were used as independent variables which influenced on the dependent variable.

\subsubsection{Attitude Scale}

We applied 6 questions on the two-point scale (Using 1 for positive and 2 for negative values) to measure managers' values. Questions included range of managers' feelings about advantage of using new energy resources. The medium value for this item is 1.5 . Therefore if mean value is less than 1.5 , these values are suitable. Reliability of the scale was 0.87 . For measuring Beliefs of managers, we used 10 questions on the five-point likert scale ranging from "strongly disagree" (1) to "strongly agree" (5). Questions included range of managers' awareness about advantage of using new energy resources. The medium value for this item is 3 . Therefore if mean value is more than 3 , these Beliefs are suitable. Reliability of the scale was 0.91

\subsubsection{Social Marketing Mix}

We used fourteen questions with five point likert scale using 1 for strongly disagree to 5 for strongly agree. Items include describing the current marketing mix such as: price, product, place, promotion, people and policy from managers' view points. Reliability of the scale was 0.78 .

\subsubsection{Suitable Marketing Mix}

For this item we used three open questions and wanted managers to describe the suitable marketing mix such as: price, product, place and promotion.

\section{Findings and Analysis}

\subsection{Model Evaluation}

To this study the model was evaluated by using Amos Graphic Software.

In this model, the CMIN (chi-square) value is 3.6; While CMIN is the minimum value of the discrepancy. And the best model has CMIN $=0$, if the number of degrees of freedom was suitable. The CMIN/DF (relative chi-square value) is 0.3 ; while the researcher suggests a ratio of approximately five or less 'as beginning to be reasonable for this index. The number of distinct parameters being estimated (NPAR) for this model is 22 and the degrees of freedom for testing the model (DF) is 13. The Tucker-Lewis Index (TLI) value for this model is 1 ; while the typical range for TLI lies between zero and one, but it is not limited to that range. TLI values close to 1 indicate a very good fit. The Root Mean Squared Error of Approximation (RMSEA) index for this model is 0; while a value of the RMSEA of about .05 or less would indicate a close fit of the model in relation to the degrees of freedom. The PCFI value for this model is 0.62 ; while PCFI is the result of applying the parsimony adjustment to the CFI and PCFI values close $>0.5$ indicate a good fit. The AIC value for this model is 47 ; while the best model has AIC $0=0$. 


\subsection{Findings}

Belief measuring results (Table 1) showed that there is a good awareness with mean value of 4.11 and sign=0 in local managers sector of Isfahan about advantages of new energy resources. Value measuring results (Table 2) showed that there is a good a feelings with mean value of 1.1 and sign $=0$ in local managers sector of Isfahan about effects of new energy resources. Suitable social marketing mix from Isfahanian local managers' viewpoint described as follow: the best place for audience to access social marketing messages in order to deliver marketing messages was at work with value 55\% (Figure 2). The cost of manager involvement to change their Attitudes was low with mean of 1.92 (Table 4). The best media for sending messages to increase managers' awareness was TV with $20 \%$ value and then, Internet services such as website and E-mail with $19 \%$ value (Figure3), and proper characters to saying messages for managers were Energy Experts with $65 \%$ value (Figure 4). Participation of managers was good with mean value 3.59 (Table 5). The current policies and available regulation for supporting new energy resources were very good with mean value 4.34 (Table 6). The relationship between social marketing mix and managers' Attitudes in initial model (Figure 5) is 0.05 . In other words, the regression weight for social marketing mix in the prediction of Attitude is not significantly different from zero at the 0.05 level (two-tailed), and when social marketing mix goes up by 1 standard deviation; Attitude goosed up only by 0.05 . as the results showed regression weight for social marketing mix in the prediction of policy and product is not significantly different from zero at the 0.05 level (two-tailed), $(\mathrm{p}=0.03)$. For improving this model, first this relationship deleted from initial model. Then the connection between Attitude and Product, Attitude and Policy, D2 and D6 was added (Table 7). Finally the improved model (Figure 6) showed that the regression weight for social marketing mix in the prediction of Price, Promotion, place and people is significantly different from zero at the 0.001 level (two-tailed). And the regression weight for social marketing mix in the prediction of Attitude is not significantly different from zero at the 0.05 level (two-tailed). Also the relation between social marketing mix and promotion, people, place is positive but this relation with price is negative. Moreover the relation between Attitudes and Values is positive and with Beliefs is negative. In other words, When social marketing mix goes up by 1 standard deviation, Product goes up by 0.02 , Promotion goes up by 1.14 , place goes up by 0.76 , people goes up by 0.02 standard deviations but price goes down by 0.09 . Also when Attitude goes up by 1 standard deviation, Beliefs goes down by 1.29 and values goes up by 0.13 standard deviations. Also The Default model has a discrepancy of 3.6. And Assuming that the Default model is correct, the probability of getting a discrepancy as large as 3.651 is .994. For the Default model, the discrepancy divided by degrees of freedom is $3.651 / 13=.281$.

\subsection{Hypothesis Testing}

The hypotheses were tested simultaneously using SPSS19 and Amos graphic software.

For testing the first hypothesis (the Beliefs of managers' about new energy affect Attitudes when is higher than medium), it was treated as bellow:

$\left\{\begin{array}{l}\text { H0: The mean of managers' belief about this matter is equal or less than medium. } \\ \text { H1: The mean of managers' belief about this matter is more than medium. }\end{array} \Rightarrow\left\{\begin{array}{l}\mathrm{H} 0: \mu<=3 \\ \mathrm{H} 1: \mu>3\end{array}\right.\right.$

Outcome of table 1 With Test Value 3, indicates that significantly level is less than .05(0.000) and sign for T test is positive. Then $\mathrm{H} 0$ is not supported and first hypothesis is accepted.

For testing the second hypothesis (the Values of managers' about new energy affect Attitudes when is higher than medium), it was treated as bellow:

$$
\left\{\begin{array} { l } 
{ \text { H0: The mean of managers' Values about this matter is equal or more than medium. } } \\
{ \text { H1: The mean of managers' Values about this matter is less than medium. } }
\end{array} \Rightarrow \left\{\begin{array}{l}
\mathrm{H} 0: \mu>=1.5 \\
\mathrm{H} 1: \mu<1.5
\end{array}\right.\right.
$$

Outcome of table 2 With Test Value 1.5, indicates that significantly level is less than $.05(0.000)$ and overall mean for this item is 1.1, Then $\mathrm{H} 0$ is not supported and second hypothesis is confirmed.

For testing the third hypothesis (the current social marketing programs of energy centers are higher than medium), it was treated as bellow:

$$
\left\{\begin{array} { l } 
{ \mathrm { H } 0 : \text { The mean of current social marketing programs is equal or less than medium. } } \\
{ \mathrm { H } 1 \text { : The mean of current social marketing programs is more than medium. } }
\end{array} \Rightarrow \left\{\begin{array}{l}
\mathrm{H} 0: \mu<=3 \\
\mathrm{H} 1: \mu>3
\end{array}\right.\right.
$$

Outcome of table 3 With Test Value 3, indicates that significantly level is less than .05(0.04) and overall mean for this item is 3.1, Then $\mathrm{H} 0$ is not supported and third hypothesis is confirmed.

For testing the fourth hypothesis (social marketing mix influences on managers' Attitudes), it was treated as bellow: 


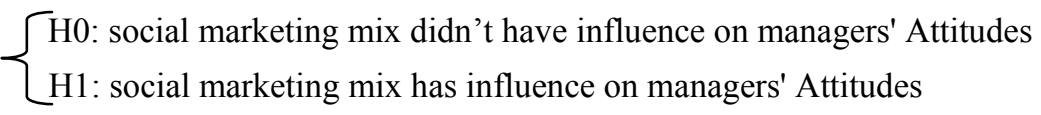

For testing this relationship we applied structural equation modeling. For this purpose, social marketing mix (SMM) and Attitudes were defined as latent variables, and measured with their components that are observed variables. Outcomes of computation standard regression in figure 5, indicate that in spite of existence positive relation between SMM and Attitudes, but regression weight for SMM in the prediction of Attitude is not significantly different from zero at the 0.05 level $(\mathrm{P}=0.45)$. Therefore $\mathrm{H} 0$ is confirmed. So this hypothesis is not supported.

For answering study question (What is suitable social marketing mix from managers' viewpoint?) used descriptive statics. The outcomes of this section indicate that, best media for delivering social marketing messages is TV (with 20\% frequencies) and internet (19\%) [Figure 3], the best place to influence on attitude is at work (55\%) [Figure 2], and the best people for delivering this messages is energy professional (43\%) [Figure 4]

As predicted by $\mathbf{H 1}$ and $\mathbf{H 2}$, the Beliefs (mean value $=4.11$ ) and Values (mean value $=1.1$ ) and consequently the Attitudes of Isfahanian local managers' were suitable. Beliefs are strongly and positively related to the awareness of managers about the new energies advantages. And Values are strongly related to the feelings of managers about the new energies effects. And as predicted by $\mathbf{H 3}$, the social marketing mix of new energy centers from target audience's viewpoint is suitable. Price $(\mathrm{P}<05$, Standardized Regression Weights $=0.07)$, promotion $(\mathrm{P}<05$, Standardized Regression Weights1.13), people $(\mathrm{P}<05$, Standardized Regression Weights 0.8$)$ and place $(\mathrm{P}<05$, Standardized Regression Weights0.77) were suitable but policy $(\mathrm{P}>05$, Standardized Regression Weights $=0.03)$ and product $(\mathrm{P}>05$, Standardized Regression Weights $=.03)$, not suitable. However H4, was predicted that social marketing mix will have positive relationship with Isfahanian local managers' Attitudes about using new energy resources, but $(\mathrm{P}>05$, Standardized Regression Weights $=0.06)$ showed that social marketing mix cant influence on managers' Attitudes. Therefore $\mathbf{H 4}$ is rejected.

\section{Conclusions}

Today's Conventional energy sources such as oil, coal, and natural gas have known as effective drivers of economic progress. Also, they have harmful impacts on environment and human health meanwhile the uses of renewable energy system, instead of conventional energy system, is useful to control the social, economical and environmental problems. Therefore Iran, as many other countries in Middle East, increasingly recognizes the need to diversify energy sources, to ensure security of supplies and provide for more consistent energy costs. Despite this significance condition, the speed of movement to use new energy in Iran is not suitable. In this study, this issue was investigated from managerial views and tried to apply social marketing principles to dissolve that. The authors used parallel mixed method (MM) for sampling, and purposive techniques to generate data for both the QUAN and QUAL standards (Teddlie\& Tashakkori, 2009:187). For data analyzing, parallel MM was used, because QUAN analysis of data used descriptive/inferential statics for the appropriate variables (Teddlie \& Tashakkori, 2009:266) such as analyzing hypothesis 1-4, and QUAL analysis of data used thematic method related the relevant narrative data (Teddlie\& Tashakkori, 2009:266) like that done for study question. Findings show that managers' awareness and feeling about the new energy advantages is very good, but in few fields it is necessary to change audiences' Attitudes. For example, attitudes towards environmental effects of new energy resources and safety principles are really poor. Therefore social marketing programs should focus on this issue and try to change this attitude. Other findings showed that current social marketing mix to influence on managers' Attitudes in order to support this industry is suitable. Also testing the relationship between Social Marketing Mix (SMM) and managers' Attitudes showed that, SMM cannot influence on managers' Attitudes for encouraging audiences to participant in development of new energy resources. In order to change negative attitudes (such as: environmental effects and safety principles), the optimal social marketing mix is suggested at table 8 .

\section{References}

Akella A. K., \& Saini R. P., \& Sharma M. P. (2009). Social, economical and environmental impacts of renewable energy systems. Renewable Energy, 34, 90-396. http://dx.doi.org/10.1016/j.renene.2008.05.002

Anderson, A. (2002). Marketing Social Marketing in the Social Change Market place. Journal of public Policy \& Marketing, 21, 3-13.

Dann, S. (2010). The AASM Summary Guide to Social Marketing Definitions. Australian National University.

Klein, J. A. (2001). Packaging Persuasion: The Incorporation of Social Marketing into Brown University's Recycling Communications. Center for Environmental Studies. Brown University. 
Klein, J. A. (2001). Packaging Persuasion: The Incorporation of Social Marketing into Brown University's Recycling Communications. Center for Environmental Studies. Brown University.

Massarrat, M. (2004). Iran's energy policy: Current dilemmas and perspective for a sustainable energy policy. International Journal of Environmental Science \& Technology, 1(3), 233-245.

Mohammadi, N. et al. (2005). Healthy Training Comprehensive Programs. Social Marketing (1st ed.). Tehran Medical science and Health services University.

Mohesh, P. (2007). Social Marketing: A communication Tool for Development. International Marketing. Conference on Marketing \& Society, IIMK.

Overwalle, F. V., \& Siebler, F. (2005). A Connectionist Model of Attitude Formation and Change. Personality and Social Psychology Review, 9(3), 231-274. http://dx.doi.org/10.1207/s15327957pspr0903_3

Perese, L., Bellringer, M., \& Abbott, M. (2005). Literature Review to Inform Social Marketing Objectives and Approaches and Behavior change Indicators to prevent and minimize Gambling harm. Wellington. New Zealand.

Peattie \& Peattie, K. (2009). Social marketing: A pathway to consumption reduction? Journal of Business Research. 62, 260-268. http://dx.doi.org/10.1016/j.jbusres.2008.01.033

Serrat, O. (2010). The Future of Social Marketing. Asian Development Bank. Mandaluyong City.

Schafer, R. B., \& Tait, J. L. (1986). A Guide for Understanding Attitudes and Attitude Change. North Central Region Extention Sociology Committee. NO.138, Iowa State University.

Smith, W. A., \& Strand J. (2008). Social Marketing Behavior A Practical Resource for Social Change Professionals. Academy for Educational Development, Washington dc.

Teddlie, Ch., \& Tashakkori, A. (2009). Foundations of Mixed Methods Research. California: SAGE Publications.

Wymer, W. (2010). Rethinking the boundaries of social marketing: Activism or advertising? Journal of Business Research, 63, 99-103. http://dx.doi.org/10.1016/j.jbusres.2009.02.003

Table 1. Mean of beliefs

\begin{tabular}{|c|c|c|c|c|c|c|}
\hline \multicolumn{7}{|c|}{ One-Sample Test } \\
\hline & \multicolumn{6}{|c|}{ Test Value $=3$} \\
\hline & \multirow[t]{2}{*}{$\mathbf{t}$} & \multirow[t]{2}{*}{ df } & \multirow[t]{2}{*}{$\begin{array}{l}\text { Sig. } \\
\text { (2-taile } \\
\text { d) }\end{array}$} & \multirow[t]{2}{*}{$\begin{array}{c}\text { Mean } \\
\text { Difference }\end{array}$} & \multicolumn{2}{|c|}{$\begin{array}{l}\text { 95\% Confidence } \\
\text { Interval of the } \\
\text { Difference }\end{array}$} \\
\hline & & & & & Lower & Upper \\
\hline BEL1 & 23.614 & 107 & .000 & 1.47 & 1.35 & 1.60 \\
\hline BEL2 & 25.369 & 107 & .000 & 1.47 & 1.36 & 1.59 \\
\hline BEL3 & 23.820 & 107 & .000 & 1.52 & 1.39 & 1.64 \\
\hline BEL5 & 13.427 & 107 & .000 & 1.23 & 1.05 & 1.41 \\
\hline BEL6 & 22.537 & 106 & .000 & 1.48 & 1.35 & 1.61 \\
\hline BEL7 & 8.831 & 107 & .000 & .95 & .74 & 1.17 \\
\hline BEL8 & 14.837 & 106 & .000 & 1.21 & 1.05 & 1.38 \\
\hline BEL10 & 8.593 & 104 & .000 & .90 & .70 & 1.11 \\
\hline BEL11 & 14.177 & 106 & .000 & 1.13 & .97 & 1.29 \\
\hline BEL12 & 17.958 & 106 & .000 & 1.38 & 1.23 & 1.54 \\
\hline BEL13 & 10.977 & 104 & .000 & .96 & .79 & 1.14 \\
\hline BEL14 & 4.214 & 106 & .000 & .51 & .27 & .76 \\
\hline BEL15 & 6.825 & 106 & .000 & .65 & .46 & .84 \\
\hline BEL16 & 3.710 & 106 & .000 & .32 & .15 & .49 \\
\hline BELIEFS & 25.041 & 107 & .000 & 1.11 & 1.02 & 1.20 \\
\hline
\end{tabular}


Table 2. Mean of values

\begin{tabular}{|c|c|c|c|c|c|c|}
\hline \multicolumn{7}{|c|}{ One-Sample Test } \\
\hline & \multicolumn{6}{|c|}{ Test Value $=1.5$} \\
\hline & \multirow[t]{2}{*}{$\mathbf{t}$} & \multirow[t]{2}{*}{ df } & \multirow[t]{2}{*}{$\begin{array}{c}\text { Sig. } \\
\text { (2-tailed } \\
\text { ) }\end{array}$} & \multirow[t]{2}{*}{$\begin{array}{c}\text { Mean } \\
\text { Difference }\end{array}$} & \multicolumn{2}{|c|}{$\begin{array}{l}\text { 95\% Confidence } \\
\text { Interval of the } \\
\text { Difference }\end{array}$} \\
\hline & & & & & Lower & Upper \\
\hline emo1 & 28.918 & 98 & .000 & 1.455 & 1.35 & 1.55 \\
\hline emo3 & 37.736 & 103 & .000 & 1.096 & 1.04 & 1.15 \\
\hline emo5 & 40.313 & 101 & .000 & 1.078 & 1.03 & 1.13 \\
\hline emo6 & 55.303 & 104 & .000 & 1.038 & 1.00 & 1.08 \\
\hline emo7 & 29.118 & 102 & .000 & 1.252 & 1.17 & 1.34 \\
\hline emo8 & 34.796 & 104 & .000 & 1.124 & 1.06 & 1.19 \\
\hline emo9 & 28.954 & 100 & .000 & 1.436 & 1.34 & 1.53 \\
\hline emo10 & 28.355 & 99 & .000 & 1.390 & 1.29 & 1.49 \\
\hline values & 30.410 & 107 & .000 & 1.096 & 1.02 & 1.17 \\
\hline
\end{tabular}

Table 3. Mean of social marketing programs

\begin{tabular}{|c|c|c|c|c|c|c|}
\hline \multicolumn{7}{|c|}{ One-Sample Test } \\
\hline & \multicolumn{6}{|c|}{ Test Value $=3$} \\
\hline & \multirow[t]{2}{*}{$\mathbf{t}$} & \multirow[t]{2}{*}{ df } & \multirow[t]{2}{*}{$\begin{array}{c}\text { Sig. } \\
\text { (2-taile } \\
\text { d) }\end{array}$} & \multirow[t]{2}{*}{$\begin{array}{c}\text { Mean } \\
\text { Difference }\end{array}$} & \multicolumn{2}{|c|}{$\begin{array}{c}\text { 95\% Confidence } \\
\text { Interval of the } \\
\text { Difference } \\
\end{array}$} \\
\hline & & & & & Lower & Upper \\
\hline PROMOTIO & 5.464 & 107 & .000 & .37 & .23 & .50 \\
\hline PRODUCT & -13.652 & 107 & .000 & -1.00 & -1.15 & -.85 \\
\hline PLACE & 2.986 & 107 & .004 & .22 & .07 & .36 \\
\hline PRICE & -9.285 & 107 & .000 & -.99 & -1.20 & -.78 \\
\hline PEOPLE & 6.543 & 107 & .000 & .54 & .37 & .70 \\
\hline POLICY & 31.153 & 107 & .000 & 1.32 & 1.24 & 1.40 \\
\hline $\begin{array}{c}\text { SOCIAL } \\
\text { MARKETING } \\
\text { MIX }\end{array}$ & 1.801 & 107 & .074 & .0748 & -.0075 & .1571 \\
\hline
\end{tabular}

Table 4. Mean of price

\begin{tabular}{|c|c|c|c|c|c|c|}
\hline \multicolumn{7}{|c|}{ One-Sample Test } \\
\hline & \multicolumn{6}{|c|}{ Test Value $=3$} \\
\hline & \multirow[t]{2}{*}{$\mathbf{t}$} & \multirow[t]{2}{*}{ df } & \multirow[t]{2}{*}{$\begin{array}{c}\text { Sig. } \\
\text { (2-tailed) }\end{array}$} & \multirow[t]{2}{*}{$\begin{array}{c}\text { Mean } \\
\text { Difference }\end{array}$} & \multicolumn{2}{|c|}{$\begin{array}{c}95 \% \text { Confidence Interval } \\
\text { of the Difference }\end{array}$} \\
\hline & & & & & Lower & Upper \\
\hline pri1 & -.786 & 93 & .434 & -.064 & -.23 & .10 \\
\hline pri3 & 4.130 & 91 & .000 & .359 & .19 & .53 \\
\hline pri4 & -4.741 & 82 & .000 & -.602 & -.86 & -.35 \\
\hline pri5 & -9.422 & 76 & .000 & -.961 & -1.16 & -.76 \\
\hline price & -9.285 & 107 & .000 & -.993 & -1.20 & -.78 \\
\hline
\end{tabular}


Table 5. Mean of people

\begin{tabular}{|c|c|c|c|c|c|c|}
\hline \multicolumn{2}{|c|}{} & \multicolumn{7}{|c|}{ One-Sample Test } \\
\cline { 2 - 7 } & $\mathbf{t}$ & df & $\begin{array}{c}\text { Sig. } \\
\text { (2-taile } \\
\text { d) }\end{array}$ & $\begin{array}{c}\text { Mean } \\
\text { Difference }\end{array}$ & \multicolumn{2}{c|}{$\begin{array}{c}\text { 95\% Confidence } \\
\text { Interval of the } \\
\text { Difference }\end{array}$} \\
\cline { 3 - 7 } & & & & .731 & .53 & .93 \\
\hline peo1 & 7.326 & 107 & .000 & .537 & .37 & .70 \\
\hline people & 6.543 & 107 & .000 & .343 & .13 & .55 \\
\hline peo2 & 3.251 & 107 & .002 & & & Upper \\
\hline
\end{tabular}

Table 6. Mean of Policy

\begin{tabular}{|c|c|c|c|c|c|c|}
\hline \multicolumn{7}{|c|}{ One-Sample Test } \\
\hline & \multicolumn{6}{|c|}{ Test Value $=3$} \\
\hline & \multirow[t]{2}{*}{$\mathbf{t}$} & \multirow[t]{2}{*}{ df } & \multirow[t]{2}{*}{$\begin{array}{c}\text { Sig. } \\
\text { (2-tailed) }\end{array}$} & \multirow[t]{2}{*}{$\begin{array}{c}\text { Mean } \\
\text { Difference }\end{array}$} & \multicolumn{2}{|c|}{$\begin{array}{l}\text { 95\% Confidence } \\
\text { Interval of the } \\
\text { Difference }\end{array}$} \\
\hline & & & & & Lower & Upper \\
\hline polic2 & 18.771 & 107 & .000 & 1.204 & 1.08 & 1.33 \\
\hline policy & 31.153 & 107 & .000 & 1.319 & 1.24 & 1.40 \\
\hline
\end{tabular}

Table 7. Analyzing index between social marketing mix and managers attitude

\begin{tabular}{|c|c|c|c|c|c|c|}
\hline Index & $\begin{array}{l}\text { Initial } \\
\text { model }\end{array}$ & $\begin{array}{c}\text { Improvement } \\
\text { model } \\
\text { by deleting } \\
\text { product }<---S M M \\
\end{array}$ & $\begin{array}{c}\text { Improvement } \\
\text { model } \\
\text { by deleting } \\
\text { policy<---SMM } \\
\end{array}$ & $\begin{array}{c}\text { Improvement } \\
\text { model } \\
\text { by adding } \\
\text { Product<---Attitude }\end{array}$ & $\begin{array}{c}\text { Improvement } \\
\text { model } \\
\text { by adding } \\
\text { Price<---Attitude } \\
\end{array}$ & $\begin{array}{c}\text { Improvement } \\
\text { model } \\
\text { by adding } \\
\text { D6 } \longrightarrow \text { D4 }\end{array}$ \\
\hline NPAR & 25 & 24 & 23 & 25 & 24 & 26 \\
\hline CMIN & 49.6 & 49.7 & 49.9 & 24.3 & 30.6 & 18 \\
\hline DF & 19 & 20 & 21 & 19 & 20 & 18 \\
\hline $\mathbf{P}$ & 0 & 0 & 0 & 0.18 & 0.06 & 0.45 \\
\hline CMIN/DF & 2.6 & 2.5 & 2.4 & 1.3 & 1.5 & 1 \\
\hline TLI & 0.94 & 0.91 & 0.92 & 0.99 & 0.97 & 1 \\
\hline PCFI & 0.64 & 0.67 & 0.70 & 0.7 & 0.7 & 0.65 \\
\hline RMSEA & 0.12 & .11 & .11 & 0.05 & 0.07 & 0.01 \\
\hline AIC & 99.6 & 97.7 & 95.9 & 74.3 & 78.5 & 70 \\
\hline
\end{tabular}

Table 8. Suitable marketing mix in order to influence on managers attitude

\begin{tabular}{|l|l|}
\hline Social marketing mix & Suitable social marketing programs \\
\hline product & $\begin{array}{l}\text { New energies is clear energy for constant } \\
\text { development }\end{array}$ \\
\hline place & At work by face to face session \\
\hline price & Consideration both monetary and emotional costs \\
\hline Promotion & $\begin{array}{l}\text { Communication tools: Public relation and advertising } \\
\text { and personal selling } \\
\text { Media: } \mathrm{TV}, \text { Internet (web site) and printed material } \\
\text { (newspaper and specialty margins) }\end{array}$ \\
\hline people & Using people viewpoint to design programs \\
\hline policy & Using all of social marketing means instead advertising \\
\hline
\end{tabular}



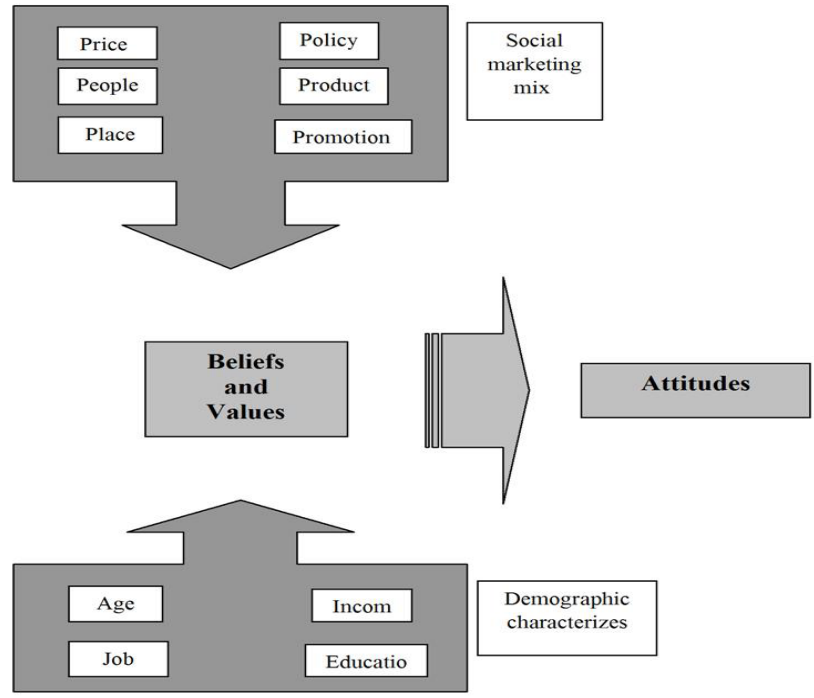

Figure 1. Model of study

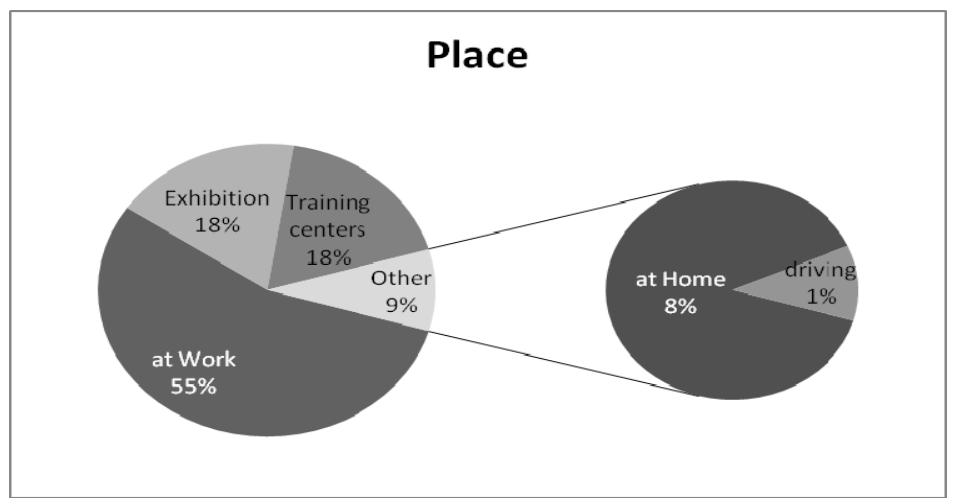

Figure 2. Suitable place from manager's viewpoint

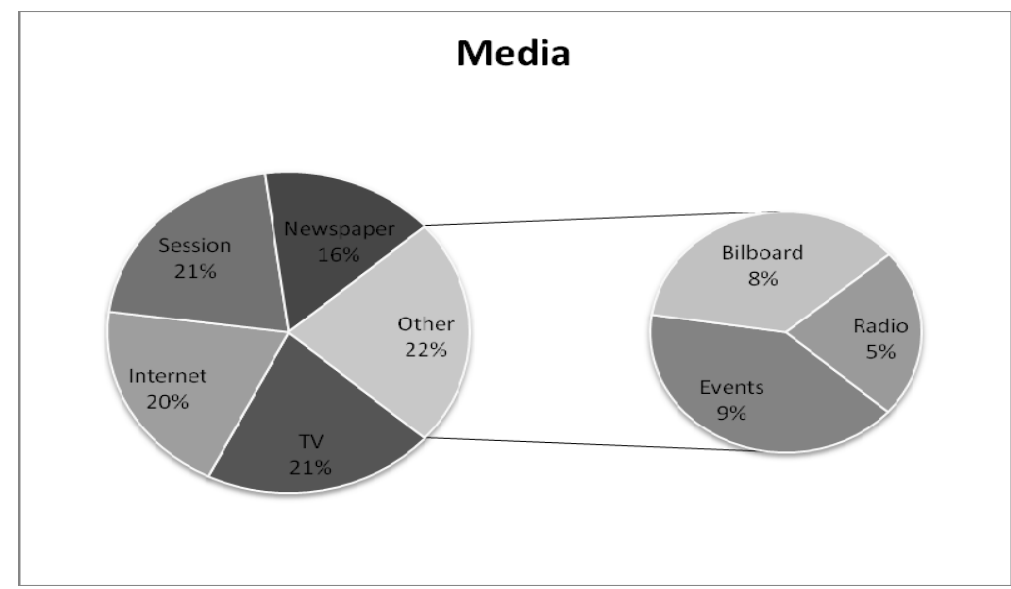

Figure 3. Suitable promotion effort (media) from manager's viewpoint 


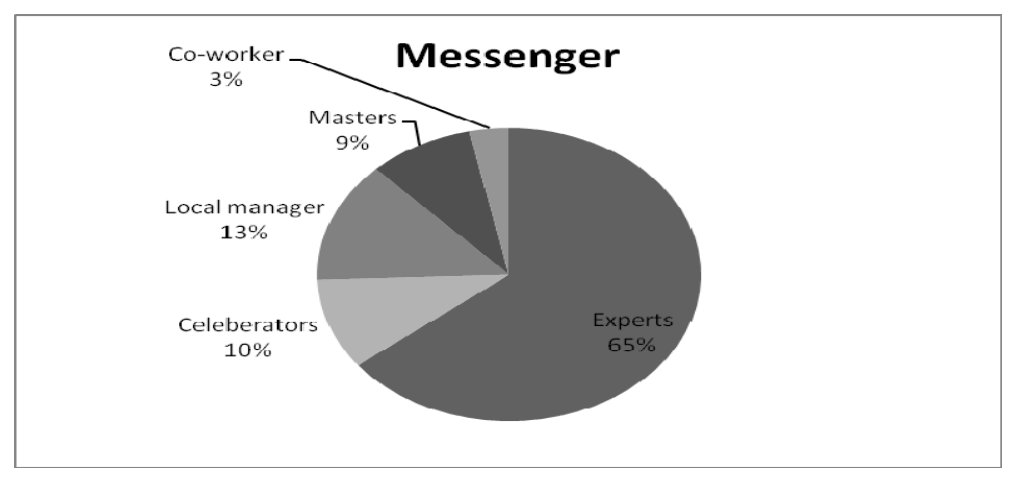

Figure 4. Suitable promotion effort (messenger) from manager's viewpoint

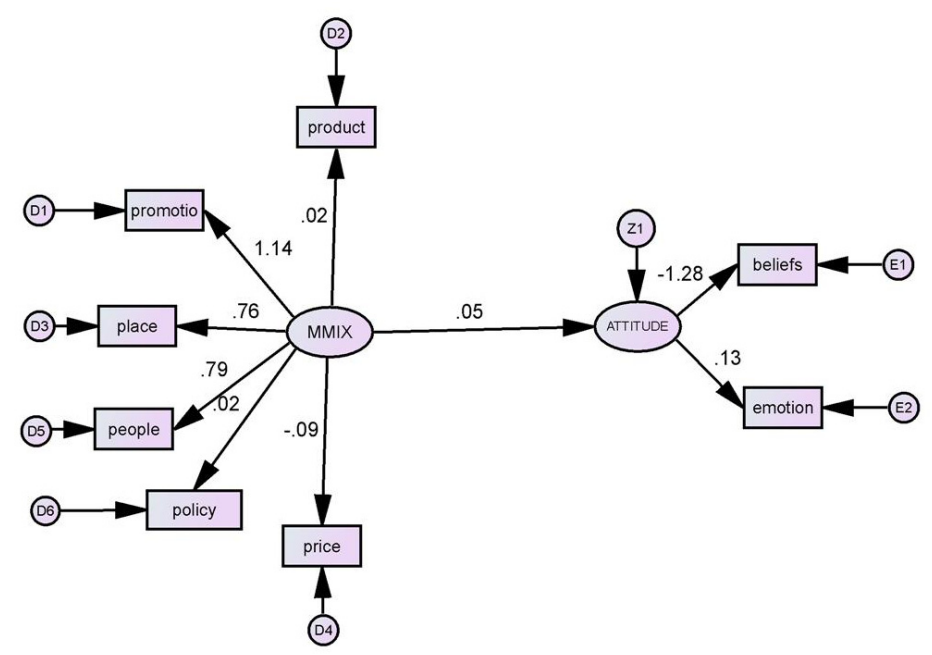

\begin{tabular}{|c|c|c|c|c|c|c|c|c|c|}
\hline Index & NPAR & CMIN & DF & P & CMIN/DF & TLI & PCFI & RMSEA & AIC \\
\hline Score & 25 & 49.6 & 19 & 0 & 2.6 & 0.94 & 0.64 & 0.12 & 99.6 \\
\hline
\end{tabular}

Figure 5. Relationship and modification index between social marketing mix and values

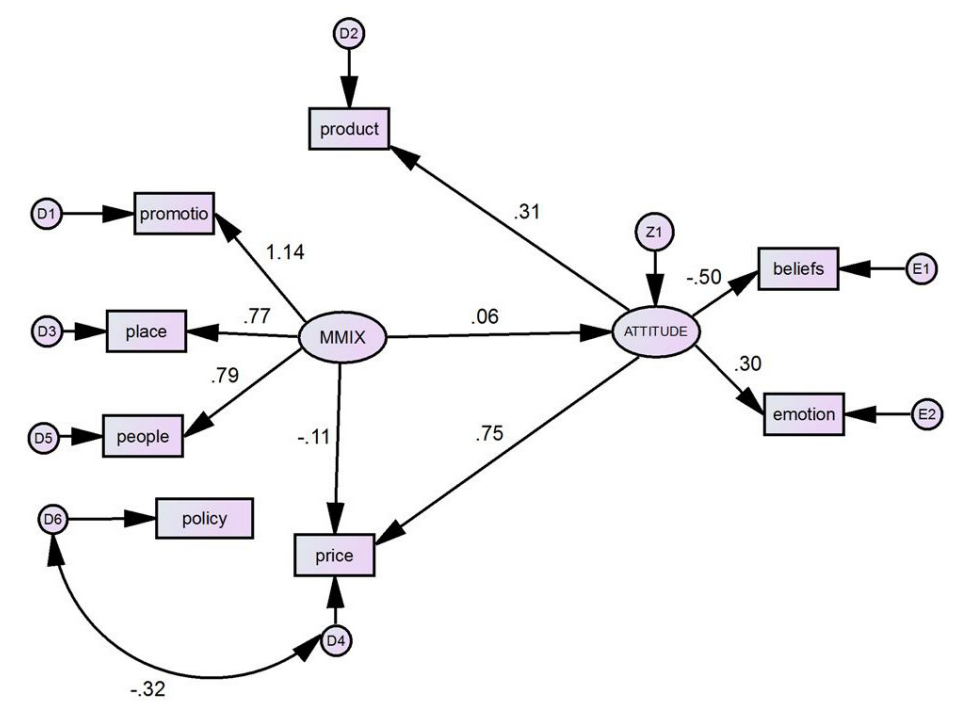

Figure 6. Improved model between social marketing mix and values 


\section{Questionnaire of study}

The bellow questions were designed for a research study. Please answer these questions carefully.

Age: Gender: education:

Income: Vocation:

Please circle the number that most closely reflects your opinion.

Q1: How are your beliefs about new energy effects?

Q1.1: New energies developments lead to technology development.

Q1.2: New energies developments lead to knowledge development.

Q1.3: New energies developments lead to increasing occupation.

Q1.4: using new energy lead to preservation rare fossil sources.

Q1.5: new energies are useful for environment by reducing fossil fuel.

Q1.6: new energies will to cause constant development.

$\begin{array}{lllll}1 & 2 & 3 & 4 & 5\end{array}$

Q1.7: new energies have been meaningful sources for producing electric energy.

$\begin{array}{lllll}1 & 2 & 3 & 4 & 5\end{array}$

Q1.8: new energies have been less pollution in comparison with other energy sources.

$\begin{array}{lllll}1 & 2 & 3 & 4 & 5\end{array}$

Q1.9: new energies have been better safety situation in comparison with other energy sources. $\begin{array}{lllllllll}1 & 2 & 3 & 4 & 5\end{array}$

Q1.10: new energies have been less cost in comparison with other energy sources.

$\begin{array}{lllll}1 & 2 & 3 & 4 & 5\end{array}$

Please sign table that most closely reflects your opinion.

Q2: How are your Values about new energy effects?

\begin{tabular}{|c|l|l|}
\hline Item & Positive(+) & Negative(-) \\
\hline Environment & & \\
\hline $\begin{array}{c}\text { Technology } \\
\text { development }\end{array}$ & & \\
\hline occupation & & \\
\hline Social development & & \\
\hline Energy production & & \\
\hline healthy & & \\
\hline
\end{tabular}

Q3: where is best place to access new energy massages from your viewpoint?

At work ( )

Training centers ( ) at home ( )

Driving ( )
Exhibition ( )

Else.

Q4: what is best Media to delivering new energy massages from your viewpoint?

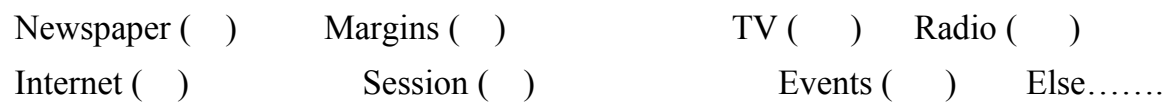

Q5: who are best People to delivering new energy massages from your viewpoint?

\begin{tabular}{|c|c|c|}
\hline Energy experts ( ) & Professors ( ) & Local managers ( \\
\hline
\end{tabular}

Q6: How do you assessment current social marketing mix of new energy centers? 


\begin{tabular}{|c|c|c|c|c|c|c|}
\hline SMM & Item & $\begin{array}{c}1 \\
\text { (very disagree) }\end{array}$ & 2 & 3 & 4 & $\begin{array}{l}5 \\
\text { (very agree) }\end{array}$ \\
\hline \multirow{5}{*}{ Promotion } & $\begin{array}{l}\text { New energy centers Radio and TV advertising } \\
\text { is suitable }\end{array}$ & & & & & \\
\hline & $\begin{array}{l}\text { Informing from Congress and conferences is } \\
\text { suitable. }\end{array}$ & & & & & \\
\hline & $\begin{array}{l}\text { TV interview with new energy center } \\
\text { managers lead to increasing people knowledge } \\
\text { about new energy effects. }\end{array}$ & & & & & \\
\hline & $\begin{array}{l}\text { Newspaper article about new energy effects are } \\
\text { suitable. }\end{array}$ & & & & & \\
\hline & $\begin{array}{l}\text { Face to face session energy center managers } \\
\text { with people lead to increasing their knowledge. }\end{array}$ & & & & & \\
\hline \multirow{3}{*}{ Place } & $\begin{array}{l}\text { New Energy knowledge is accessible at home } \\
\text { by TV and Radio. }\end{array}$ & & & & & \\
\hline & $\begin{array}{l}\text { New Energy knowledge is accessible at work } \\
\text { by internet and margins. }\end{array}$ & & & & & \\
\hline & $\begin{array}{l}\text { New Energy knowledge is accessible at } \\
\text { training centers. }\end{array}$ & & & & & \\
\hline \multirow[t]{2}{*}{ Product } & $\begin{array}{l}\text { New energies are useful for environment by } \\
\text { reducing pollution. }\end{array}$ & & & & & \\
\hline & New energies are constant energy. & & & & & \\
\hline \multirow{2}{*}{ People } & $\begin{array}{l}\text { Delivering knowledge by new energy } \\
\text { managers lead to increasing audiences } \\
\text { awareness about new energy. }\end{array}$ & & & & & \\
\hline & $\begin{array}{l}\text { Face to face relation between new energy } \\
\text { worker and audiences lead to increasing their } \\
\text { awareness about new energy. }\end{array}$ & & & & & \\
\hline \multirow[b]{2}{*}{ Policy } & New energy centers policies is suitable & & & & & \\
\hline & $\begin{array}{l}\text { Government regulation to support new energy } \\
\text { development is suitable. }\end{array}$ & & & & & \\
\hline
\end{tabular}

